\title{
A Human Matter (Rzecz ludzka)
}

Author: Mieczysław Jastrun

First Published: 1946

Translations: Slovak (Mlkve monology [selection], 1964); English ("Here Too As In Jerusalem": Selected Poems of the Ghetto; in Polish Review, 10(3), pp. 22-42, 1965 [poems of Jastrun and other Polish poets]; Memorials: A Selection, 2014).

About the Author: Mieczysław Jastrun (1903-1983), a poet, essayist, and prose writer, was born in Korolówka (in former Eastern Galicia) to a Jewish family as Mojsze Agatsztein. At the age of seventeen he changed both his religion and his surname, and never fully accepted his Jewish origin. He studied Polish, German philology, and philosophy at the Jagiellonian University in Cracow. Jastrun made his literary debut in the prewar period with his poem The Big Wagon (Wielki Wagon), which was published in the monthly magazine Skamander in 1925. He worked as a Polish language teacher, translator, magazine editor (Wiadomości Literackie, Ateneum, Gazeta Literacka), and also lectured on contemporary poetry at the University of Warsaw. After the beginning of World War II, he escaped to Lviv occupied by the Soviets, and in 1941 returned to Poland spending his time in illegality and hidings. In 1964, he signed "Letter 34", a protest letter by writers and scholars in defence of freedom of speech.

Further Important Publications: Spotkanie w czasie (1929, Meeting in Time; poems); Inna młodość (1933, Another Youth; poems); Dzieje nieostygłe (1935, History Is Not Cooling Down; poems); Strumień milczenia (1937, Stream of Silence; poems); Potęga ciemnoty (1945, The Power of Ignorance, essay).

\section{Content and Interpretation}

Jastrun's wartime poetry collection A Human Matter was featured prominently in From the Abyss ( $\mathrm{Z}$ otchłani, 1944), the first anthology of Polish poetry related to the Holocaust, alongside works by Czesław Miłosz ( $\rightarrow$ Selected Poetry) and Michał Borwicz $(\rightarrow$ The Song Will Survive...). Although some of Jastrun's poems got burned during the war, he later managed to piece them together from memory. As Natan Gross points out, the situation of a Jew hiding on Aryan papers appears in almost every poem in the collection (Gross, 1993, p. 128). Jastrun, who did not write poetry about the Jewish experience before the war, deals here explicitly with the Holocaust, especially in his poems Memory (Wspomnienie, 1944) and Dedication (Dedykacja, 1945), with less direct allusions in such poems as Looking into the Eyes (Spojrzenie w oczy, 1944) and On the Ruins (Na zgliszczach, 1945). The third, fourth, and fifth stanzas in Dedication are devoted to the Warsaw Ghetto Uprising juxtaposed to verses on the Warsaw Uprising of 1944. In Folk Song (Pieśń gminna, 1945), Jastrun compares the ruins of Warsaw to

Ә Open Access. () 2021 Anna Foltyniak-Pękala, Agata Firlej, published by De Gruyter. (cc)BY-NC-ND This work is licensed under a Creative Commons Attribution-NonCommercial-NoDerivatives 4.0 License. https://doi.org/10.1515/9783110671056-050 
Carthage and Jerusalem, in this way connecting Mediterranean and Semitic cultures two societies that had lived side by side in Warsaw for hundreds of years. The lyrical subject remains pessimistic about the future and the possibility of avoiding persecution and disasters. As he claims in the poem On the Ruins, people will never learn, never adhere to any moral standard. Others, rejected by society, will die in solitude as strangers. The war and occupation demonstrated that the existing poetic language and means of expression did not match the new reality. Jastrun thus set out in search of a new means of expression, a new poetic language, and found inspiration in the figure of Cyprian Kamil Norwid, one of the most famous Polish poets of the 19th century. Norwid's oeuvre belongs mainly to Romanticism, but it also influenced the Polish modernists (including Jastrun). Various elements in the latter's works can be traced to Norwid: the motif of random and anonymous death, for instance, and comparisons between a lifeless man and slaughtered ox; the city pavement as silent "witness" of a crime; the question of death as a harmonious end to human life; the condemnation of crime, and human inclination to sacralise and mythologise acts of vengeance (Dakowicz, 2010). The title of the collection was also taken from Norwid's poem It's a Human Matter! (To rzecz ludzka!, 1844).

In the face of a suddenly quite inhuman reality, Jastrun's collection is a farewell to prewar poetry and language, and a search for a new language and poetic forms that will be more adequate to the task.

\section{Main Topics and Problems}

The war was a turning point in the writer's work, in the sense that the cruelty he witnessed and experienced compelled him to reassess his values and search for new techniques and subject matter for his poetry.

Jastrun's work aims above all to describe this cruelty and the suffering of ordinary people, to convey humiliation and dehumanisation on a universal scale. It is no wonder then that he should focus on Shoah and the mass extermination of the Jews. Most of the poems in Song of a Jewish Boy (Pieśń chłopca żydowskiego, 1946) show the enormity of the crimes against the Jews, as well as the sadness and brutality that they experienced. Even after the war, Jastrun remained silent about his own Jewish identity, referring to it only indirectly. Perhaps it was the Hell he witnessed during the war, much of which he spent in hiding or on the move, that persuaded him to keep it concealed in the postwar period (Gross, 1993, p. 127).

In his essay The Power of Stupidity (1945), Jastrun attacks Polish antisemitism, as well as the widespread indifference in Poland towards the Holocaust, and he condemns those Poles who collaborated with the Nazis in the mass extermination. These issues are raised again in his poem The Jews (Żydzi, 1944, 1945, previously untitled), which begins with the inscription "Here as in Jerusalem". While an earlier wartime version of the poem addresses Polish indifference towards the persecution of Jews in more explicit terms, these verses were removed from a second revised version and a final stanza was added describing a ghetto in ruins adjacent to a cross, Christian sym- 
bol of devotion and suffering. Natan Gross has interpreted this mysterious gesture as a gesture of "gratitude to the people who saved him" (Gross, 1993, p. 126), but adds that it was probably not easy for Jastrun, in the face of ongoing antisemitism during the postwar period, to tone down his accusation. These changes reveal the poet's dilemma, torn between the desire to bear witness to the persecution of the Jews and give due credit to the "ten righteous" Poles who helped to save their Jewish compatriots (p. 126).

In the postwar years, Jastrun's work turns primarily to history and the meaning of past events, a tendency connected with his deep interest in Polish Romanticism.

In the period after 1989, as public life in Poland shifted once more, Jastrun's status and achievements in the context of Polish literature have gone through a process of revision. Right-wing circles have disavowed his work and tried to depict him as a Communist Jewish traitor. Though some defended him, notably those artists who remembered Jastrun personally (like T. Nowak), Jastrun's work eventually disappeared from school textbooks and he became a forgotten poet.

\section{Cited Works}

Dakowicz P., (2010) Historia - rzecz ludzka? Tradycja Norwidowska w wierszach Mieczysława Jastruna z lat 1939-1945. Acta Universitas Lodziensis, Folia Litteratura Polonica, 40(13), pp. 217-244. Gross, N. (1993). Żydowski problem Mieczysława Jastruna. In: N. Gross, Poeci i Szoa. Obraz zagłady Żydów w poezji polskiej. Sosnowiec: OFFMAX, pp. $125-129$.

\section{Further References}

Czachowska. J., Szałgan, A., eds. (2014). Wspótcześni polscy pisarze i badacze literatury. Stownik biobibliograficzny, vol. 3., Warszawa: Wydawnictwa Szkolne i Pedagogiczne. Hoffman, M. L. (2001). Empathy and Moral Development: Implication for Caring and Justice. Cambridge: Cambridge University Press. Killmann, J. (2014). Der Dichter Mieczysław Jastrun: Eine bibliographische Monographie. Mühlheim a.M.: Selbstverlag. Mielhorski, R. (2003). „Sprawa Jastruna“? (w świetle wypowiedzi publicystyczno-krytycznych i nowych publikacji po 1989 roku - rekonesans). Literaturoznawstwo: historia, teoria, metodologia, krytyka, 1(6)-2(7), pp. 111-141. Pennebaker, J. W. (1992). Overcoming Traumatic memories. In: S. Christianson, ed., The Handbook of Emotion and Memory: Research and Theory. Hillsdale: Taylor \& Francis, pp. 102-104. ProkopJaniec, E. (2001). Żyd - Polak - artysta. O budowaniu tożsamości po Zagładzie. Teksty Drugie, 12(1), pp. 120-134. Trznadel, J. (1953). O poezji Mieczysława Jastruna. Pamiętnik Literacki, 44(1), pp. 71-112.

$\mathrm{AFP}-\mathrm{AF}$ 